\title{
PENERAPAN BEBAN PEMBUKTIAN OLEH HAKIM DALAM PENYELESAIAN SENGKETA DI PENGADILAN TATA USAHA NEGARA
}

\author{
Bayu Septiawan \\ Fakultas Hukum Universitas Bengkulu \\ bayuseptiawan494@gmail.com
}

\begin{abstract}
This study aims to find out the application of proof burden on the Bengkulu State Administrative Court according to Article 107 of the Law on State Administrative Judgment and to know the judge's judgment in determining the burden of proof in Bengkulu State Administrative Court. The method used in this study is empirical legal research method, in this study the data used are primary data and secondary data. Then the data is analyzed by qualitative juridical in a deductive-inductive way of thinking. Based on the results of the research that the authors do, it can be concluded that the implementation of burden of proof in the Bengkulu State Administrative Court, from Year 2015-2017 which amounts to thirty (30) cases in the Bengkulu State Administrative Court, the Judge never determines the burden of proof, as Regulated in Article 107, the Judge determines the burden of proof to either party both the Plaintiff and the Defendant. But both are even more likely to the Plaintiffs to prove the first evidence of the proceedings filed in the trial as is usually in the civil justice law system. Of the thirty (30) decrees that have been reviewed and based on the results of the interview, it appears that judges do not find evidence of the burden of proof on either party both the Plaintiff and the Defendant, so it can be concluded that the Judge never determines the burden of proof.
\end{abstract}

Keywords: Administrative Court; Implementation Load Proof; The Judge

\begin{abstract}
Abstrak
Penelitian bertujuan untuk menganalisis penerapan beban pembuktian di Pengadilan Tata Usaha Negara Bengkulu menurut Pasal 107 Undang-Undang tentang Peradilan Tata Usaha Negara dan mengetahui pertimbangan hakim dalam menentukan beban pembuktian di Pengadilan Tata Usaha Negara Bengkulu. Metode yang digunakan dalam penelitian ini ialah metode penelitian hukum empiris, dalam penelitian ini data yang digunakan ialah data primer dan data sekunder. Kemudian data dianalisis secara yuridis kualitatif dengan cara berpikir deduktif-induktif. Berdasarkan dari hasil penelitian penulis lakukan, maka dapat disimpulkan bahwa Penerapan beban pembuktian di Pengadilan Tata Usaha Negara Bengkulu, dari Tahun 2015-2017 yang berjumlah 30 (tiga puluh) berkas perkara di Pengadilan Tata Usaha Negara Bengkulu, Hakim tidak pernah menentukan beban pembuktian, sebagaimana diatur dalam Pasal 107, Hakim menentukan beban pembuktian kepada salah satu pihak baik Penggugat maupun Tergugat. Melainkan kepada keduaduanya bahkan lebih cenderung kepada Penggugat untuk membuktikan terlebih dahulu alat bukti yang diajukan di persidangan seperti lazimnya dalam sistem peradilan hukum acara perdata. Terhadap 30 (tiga puluh) berkas putusan yang telah diteliti dan berdasarkan hasil wawancara, ternyata tidak ditemukan pertimbangan hakim mengenai beban pembuktian kepada salah satu pihak baik Penggugat maupun Tergugat, sehingga dapat disimpulkan bahwa Hakim tidak pernah menentukan beban pembuktian.
\end{abstract}

Kata Kunci: Pengadilan Tata Usaha Negara; Beban Pembuktian; Hakim

\section{PENDAHULUAN}

Indonesia adalah negara hukum (rechtstaat), tidak berdasarkan atas kekuasaan belaka (machstaat). Negara hukum menghendaki agar setiap tindakan

Bayu Septiawan: Penerapan Beban Pembuktian Oleh Hakim Dalam Penyelesaian Sengketa Di Pengadilan Tata Usaha Negara Bengkulu 
penguasa haruslah berdasarkan pada ketentuan hukum yang berlaku1. Di Indonesia dasar penetapan sebagai negara hukum tercantum dalam ketentuan Pasal 1 ayat (3) Undang-Undang Dasar Negara Republik Indonesia Tahun 1945, yang menyatakan Indonesia adalah negara hukum. Sesuai dengan pasal tersebut dapat dikatakan bahwa setiap tindakan yang dilakukan baik oleh pejabat, maupun masyarakat Indonesia harus sesuai dengan aturan hukum. Tidak setiap negara, dapat menetapkan dirinya sebagai negara hukum, karena untuk dapat disebut sebagai negara hukum harus memenuhi 4 unsur penting, yaitu: (1) Adanya perlindungan terhadap hak asasi manusia; (2) Adanya pemisahan/pembagian kekuasaan; (3) etiap tindakan pemerintah harus didasarkan pada peraturan perundang-undangan yang berlaku; (4) Adanya peradilan Tata Usaha Negara. ${ }^{2}$

Salah satu unsur utama negara hukum, disebutkan adanya Peradilan Tata Usaha Negara. Di Indonesia Peradilan Tata Usaha Negara diatur dengan UndangUndang Nomor 5 Tahun 1986 tentang Peradilan Tata Usaha Negara, yang diundangkan pada tanggal 29 Desember 1986. Berdasarkan Peraturan Pemerintah Nomor 7 Tahun 1991 tentang Penerapan Undang-Undang Nomor 5 Tahun 1986 tentang Peradilan Tata Usaha Negara, yang undang-undang tersebut, mulai dilaksanakan diseluruh wilayah Indonesia sejak tanggal 14 Januari 1991. UndangUndang Nomor 5 Tahun 1986 sudah dua kali perubahaan, pertama dengan Undang-Undang Nomor 9 Tahun 2004 tentang Perubahan Atas Undang-Undang Nomor 5 Tahun 1986 tentang Peradilan Tata Usaha Negara dan kedua dengan Undang-Undang Nomor 51 Tahun 2009 tentang Perubahan Kedua Atas UndangUndang Nomor 5 Tahun 1986 tentang Peradilan Tata Usaha Negara.

Peradilan Tata Usaha Negara di Indonesia sebagaimana disebutkan dalam konsideran Undang-Undang Nomor 5 Tahun 1986 tentang Peradilan Tata Usaha Negara adalah untuk menjamin persamaan kedudukan warga masyarakat dalam hukum dan menjamin terpeliharannya hubungan yang serasi, seimbang serta selaras antara aparatur dibidang Tata Usaha Negara dengan warga masyarakat. Esensi utama kehadiran PTUN sebagai peradilan administrasi adalah untuk menjaga harmoni antara kepentingan individu yang melekat dalam hak-hak warga negara dan memberi kepastian hukum terhadap kepentingan publik yang pengelolaannya di bawah kontrol pemerintah. ${ }^{3}$

Dalam asas keaktifan hakim (dominus litis) merupahkan asas yang dimaksud untuk menyeimbangkan kedudukan para pihak yang tidak seimbang antara kedudukan Pengugat dan Tergugat selaku pemegang kekuasaan publik. Dimana Hakim harus menyeimbangkan kedudukan Penggugat dan Tergugat adalah badan atau pejabat Tata Usaha Negara itu yang tentu menguasai informasi atau data yang berkaitan dengan kewenangan dan dasar dikeluarkanya keputusan yang digugat. Bahkan Hakim dapat mengatasi kesulitan orang atau badan hukum

${ }^{1}$ H. Rozali Abdullah, Hukum Acara Peradilan Tata Usaha Negara. PT. Raja Grafindo Persada, Jakarta, 2013, hlm. 11.

2 Ibid

IIrvan Mawardi, Paradigma Baru PTUN, Respon Peradilan Administrasi Terhadap Demokratisasi, Penerbit Thafa Media,Yogyakarta, 2016, hlm. 1.

Bayu Septiawan: Penerapan Beban Pembuktian Oleh Hakim Dalam Penyelesaian Sengketa Di Pengadilan Tata Usaha Negara Bengkulu 
perdata pada umumnya warga masyarakat dalam memperoleh informasi atau data yang diperlukan dari badan atau pejabat Tata Usaha Negara. Dengan demikian asas ini memberikan peran kepada hakim dalam proses persidangan guna memperoleh suatu kebenaran materiil dan untuk undang-undang tentang peradilan tata usaha negara mengarah pada pembuktian bebas. ${ }^{4}$ Bebas yang terbatas disebut ajaran pembuktian bebas yang terbatas karena alat-alat bukti yang dapat diajukan dalam membuktikan sesuatu sudah ditentukan secara limatif yang terdapat di Pasal 100 Undang-Undang tentang Peradilan Tata Usaha Negara. Sedangkan ajaran pembuktian bebas atau teori pembuktian bebas adalah ajaran teori yang tidak menghendaki adanya ketentuan-ketentuan yang mengikat hakim, sehingga sejauh mana pembuktian dilakukan dan diserahkan kepada hakim. ${ }^{5}$ Sebagaimana konsekuensi dari ajaran pembuktian bebas sebagaimana diatur dalam Pasal 107 Undang-Undang tentang Peradilan Tata Usaha Negara, yang menyatakan bahwa

Hakim menentukan apa yang harus dibuktikan, beban pembuktian berserta penilaian pembuktian, dan untuk sahnya pembuktian perlu sekurangkurangnya dua alat bukti berdasarkan keyakinan hakim. Mengenai ketentuan tentang beban pembuktian bahwa hakim Peradilan Tata Usaha Negara dapat menentukan hal apa atau fakta apa saja yang harus dibuktikan oleh hakim. Dalam hukum acara perdata, beban pembuktian diatur dalam Pasal 163 HIR/283 Rbg yang mengatakan bahwa "Barang siapa yang mendalilkan mempunyai suatu hak atau mengajukan suatu peristiwa (fiet) untuk menegaskan haknya atau membantah adanya hak orang lain, haruslah membuktikan tentang adanya hak atau peristiwa tersebut". ${ }^{6}$ Demikian pula dalam Pasal 1865 Kitab Undang-Undang Hukum Perdata, yang menyatakan bahwa : Setiap orang yang mengaku mempunyai suatu hak, atau menunjukan suatu peristiwa untuk meneguhkan haknya itu atau untuk membantah suatu hak orang lain, wajib membuktikan adanya hak itu atau kejadian yang dikemukakan itu.

Berdasarkan uraian tersebut penelitian ini bertujuan untuk mengkaji penerapan beban pembuktian di Pengadilan Tata Usaha Negara berdasarkan Pasal 107 Undang-Undang Tentang Peradilan Tata Usaha Negara, serta pertimbangan hakim dalam menentukan beban pembuktian di atas.

\section{METODE PENELITIAN}

Penelitian ini merupakan penelitian hukum yang menggunakan metode penelitian empiris dengan pendekatan sosiologis pada Pengadilan Tata Usaha Negara di Bengkulu. Pengumpulan data primer dilakukan dengan wawancara mendalam kepada Hakim dan Panitera Pengadilan Tata Usaha Negara Bengkulu,

4Fatria Khairo, Hukum AcaraPeradilan Tata Usaha Negara, Penerbit Cintya press-Jakarta, 2016, hlm. 33.

5 Yuslim, Hukum AcaraPeradilan Tata Usaha Negara, Cetakan Pertama, Sinar Grafika, Jakarta, 2015, hlm. 139.

6 R. Wiyono, Hukum AcaraPeradilan Tata Usaha Negara, Penerbit Sinar Grafika, Edisi Ketiga, Jakarta, 2013. hlm 174.

Bayu Septiawan: Penerapan Beban Pembuktian Oleh Hakim Dalam Penyelesaian Sengketa Di Pengadilan Tata Usaha Negara Bengkulu 
kuasa hukum Penggugat dan Tergugat. Data sekunder dengan studi kepustakan untuk mendapatkan data yangmendukung penyelesaian permasalahan baik dokumen-dokumen hukum seperti putusan pengadilan, jurnal dan sebagainya, maupun data non hukum. Analisis dilakukn secara kualitatif.

\section{HASIL DAN PEMBAHASAN}

\section{Penerapan Beban Pembuktian Di Pengadilan Tata Usaha Negara Bengkulu Menurut Pasal 107 Undang-Undang Tentang Peradilan Tata Usaha Negara}

Peradilan Tata Usaha Negara pada dasarnya menegakan hukum publik administrasi, sebagaimana ditegaskan dalam Undang-Undang Nomor 5 Tahun 1986 tentang Peradilan Tata Usaha Negara yang diubah dengan Undang-Undang Nomor 9 Tahun 2004 tentang Perubahan Atas Undang-Undang Nomor 5 Tahun 1986 tentang Peradilan Tata Usaha Negara dan diubah dengan Undang-Undang Nomor 51 Tahun 2009 tentang Perubahan Kedua Atas Undang-Undang Nomor 5 Tahun 1986 tentang Peradilan Tata Usaha Negara, bahwa sengketa yang termasuk lingkup kewenangan Peradilan Tata Usaha Negara adalah sengketa Tata Usaha Negara. Peradilan Tata Usaha Negara Bengkulu dari Tahun 2015 sampai 2017 telah memeriksa, memutus dan meyelesaikan sengketa, dapat dilihat pada ditabel dibawah ini.

Tabel daftar perkara Pengadilan Tata Usaha Negara Bengkulu (Tahun 2015-2017)

\begin{tabular}{|ccccc|}
\hline Tahun & $\begin{array}{c}\text { Perkara } \\
\text { Masuk }\end{array}$ & Putus & Banding & Kasasi \\
2015 & 10 & 10 & 3 & 3 \\
2016 & 20 & 20 & 14 & 7 \\
2017 & 7 & 5 & 2 & - \\
Jumlah & 37 & 35 & 19 & 10 \\
\hline
\end{tabular}

Sumber: Pengadilan Tata Usaha Negara Bengkulu, 2017

Dalam pemeriksaan di Pengadilan Tata Usaha Negara (PTUN) Bengkulu, ada dua pemeriksaan, yaitu: Pemeriksaan di Luar Persidangan dan Pemeriksaan Administrasi. Pemeriksaan Administrasi dilakukan oleh Kepaniteraan, merupakan tahap pertama untuk memeriksa gugatan yang masuk dan telah didaftar serta mendapat nomor register yaitu setelah Penggugat/kuasanya menyelesaikan administrasi dengan membayar uang panjar perkara. Undang-Undang Nomor 5 Tahun 1986 jo. Undang-Undang Nomor 9 Tahun 2004, tidak menentukan secara tegas pengaturan tentang penelitian segi administrasi terhadap gugatan yang telah masuk dan didaftarkan dalam register perkara di Pengadilan, akan tetapi dari ketentuan Pasal 62 ayat (1) huruf b Undang-Undang Nomor 5 Tahun 1986 jo. Undang-Undang Nomor 9 Tahun 2004, yang menyatakan syarat-syarat gugatan sebagaimana dimaksud dalam Pasal 56 tidak dipenuhi oleh Penggugat sekalipun telah diberitahu dan diperingatkan. 
Dalam Surat Edaran Makamah Agung Nomor 2 Tahun 1991 tentang Petunjuk Pelaksanan Beberapa Ketentuan dalam Undang-Undang Nomor 5 Tahun 1986 diatur mengenai Penelitian Administrasi:7 (1)Petugas yang berwenang untuk melakukan penelitian administrasi adalah panitera, wakil panitera, panitera muda perkara sesuai dengan pembagian tugas yang diberikan; (2). Setiap gugatan yang masuk harus segera dibubuhi stempel dan tanggal pada sudut kiri atas halaman pertama yang menunjukkan mengenai: (a) Diterimanya surat gugatan yang bersangkutan; (b) Setelah segala persyaratan dipenuhi, dilakukan pendaftaran nomor perkaranya setelah membayar panjar biaya perkara; (c). Perbaikan formal surat gugatan (jika memang ada); (3) Surat gugatan tidak perlu dibubuhi materai stempel, karena hal tersebut tidak disyaratkan oleh Undang-Undang; (4).Nomor Register perkara di Pengadilan Tinggi Tata Usaha Negara harus dipisahkan antara perkara tingkat banding dan perkara yang diajukan ke Pengadilan Tinggi Tata Usaha Negara sebagai instansi tingkat pertama (vide Pasal 48 Jo. Pasal 51 ayat 3 UU No. 5 Tahun1986); (5) Di dalam kepala surat, alamat kantor Pengadilan Tata Usaha Negara atau Pengadilan Tinggi Tata Usaha Negara harus ditulis secara lengkap termasuk kode posnya walaupun mungkin kotanya berbeda; (6) Identitas Penggugat harus dicantumkan secara lengkap dalam surat gugatan sebagaimana yang ditentukan dalam Pasal 56 UU No. 5 Tahun 1986.

Untuk memudahkan penanganan kasus-kasus dan demi keseragaman model surat gugatan harus disebutkan terlebih dahulu nama dari pihak Penggugat pribadi (in person) dan baru disebutkan nama kuasa yang mendampingi, sehingga dalam register perkara akan tampak jelas siapa pihakpihak yang berperkara senyatanya. Penelitian administrasi supaya dilakukan secara formal tentang bentuk dan isi gugatan sesuai Pasal 56 dan tidak menyangkut segi materiil gugatan. Pendaftaran perkara di tingkat pertama dan banding dimasukkan dalam register setelah yang bersangkutan membayar uang muka atau panjar biaya perkara yang ditaksir oleh panitera sesuai Pasal 59 sekurang-kurangnya sebesar Rp 50.000,00 (lima puluh ribu rupiah).

Dalam hal Penggugat bertempat tinggal jauh dari PTUN untuk mendaftarkan gugatannya, maka tentang pembayaran uang muka biaya perkara dapat ditempuh dengan cara: (a) Panjar biaya perkara dapat dibayarkan melalui PTUN mana gugatan diajukan yang terdekat dengan tempat tinggalnya. Ongkos kirim ditanggung penggugat di luar panjar biaya perkara; (b) Panjar biaya perkara dikirim langsung kepada PTUN dimana ia mendaftarkan gugatannya.

Dalam hal suatu pihak didampingi kuasa, maka bentuk Surat Kuasa Khusus dengan materai secukupnya, dan Surat Kuasa Khusus yang diberi cap jempol haruslah dikuatkan (waarmerking) oleh pejabat yang berwenang. Selanjutnya (a) Surat Kuasa Khusus bagi pengacara/advokat tidak perlu dilegalisir; (b).Dalam pemberian kuasa dibolehkan adanya substitusi tetapi dimungkinkan pula adanya kuasa insidentil;(c).Surat kuasa tidak perlu didaftarkan di Kepaniteraan PTUN.

7 Surat Edaran Makamah Agung Nomor 2 Tahun1991, Op.,Cit,. butir I

Bayu Septiawan: Penerapan Beban Pembuktian Oleh Hakim Dalam Penyelesaian Sengketa Di Pengadilan Tata Usaha Negara Bengkulu 
Untuk memudahkan pemeriksaan perkara selanjutnya maka setelah suatu perkara didaftarkan dalam register dan memperoleh nomor perkara, oleh staf kepaniteraan dibuatkan resume gugatan terlebih dahulu sebelum diajukan kepada Ketua Pengadilan, dengan bentuk formal yang isinya pada pokoknya sebagai berikut : (a) Siapa subyek gugatan, dan apakah penggugat maju sendiri ataukah diwakili oleh Kuasa; (b).Apa yang menjadi obyek gugatan, dan apakah obyek gugatan tersebut termasuk dalam pengertian Keputusan TUN yang memenuhi unsur Pasal 1 angka 3 UU No. 5 Tahun 1986; (c).Apakah yang menjadi alasanalasan gugatan, dan apakah alasan tersebut memenuhi unsur Pasal 53 ayat 2 huruf a, b, dan c UU No. 5 Tahun 1986. (Setelah keluarnya UU No. 9 Tahun 2004 alasan gugatan mendasarkan pada Pasal 53 ayat 2 huruf a dan b UU No. 9 Tahun 2004); (d) Apakah yang menjadi petitum atau isi gugatan, yaitu hanya pembatalan Keputusan TUN saja, ataukah ditambah pula dengan tuntutan ganti rugi dan/atau rehabilitasi.

Untuk penelitian syarat-syarat formal gugatan, Panitera atau staf Kepaniteraan dapat memberikan catatan atas gugatan tersebut, untuk disampaikan kepada Ketua Pengadilan untuk ditindak lanjuti dengan Prosedur Dismissal.

a. Pemeriksaan Dismissal

Pemeriksan dimissal dilakukan untuk pematang perkara sebelum dilakukan pemeriksan pokok perkara di dalam persidangan di muka sidang yang terbuka untuk umum. Proses dismissal (Pasal 62) merupahkan pemeriksaan administratif untuk menetapkan apakah suatu gugatan dapat diterima atau tidak dapat diterima. Jika dikaitkan dengan Pasal 62 tersebut memang dirumuskan "Dalam rapat permusyawaratan, Ketua Pengadilan berwenang memutuskan dengan suatu penetapan yang dilengkapi dengan pertimbangan-pertimbangan gugatan dinyatakan tidak diterima atau tidak berdasar". 8

Pasal 62 ayat (1) Undang-Undang Peradilan Tata Usaha Negara, yang menyatakan bahwa: (1) Dalam rapat permusyawaratan, Ketua Pengadilan berwenang memutuskan dengan suatu penetapan yang dilengkapi dengan pertimbangan-pertimbangan bahwa gugatan yang diajukan itu dinyatakan tidak diterima atau tidak berdasar, dalam hal: (a) pokok gugatan tersebut nyata-nyata tidak termasuk dalam wewenang Pengadilan; (b) syarat-syarat gugatan sebagaimana dimaksud dalam Pasal 56 tidak dipenuhi oleh penggugat sekalipun ia telah diberi tahu dan diperingatkan; (c) gugatan tersebut tidak didasarkan pada alasan-alasan yang layak; (d) apa yang dituntut dalam gugatan sebenarnya sudah terpenuhi oleh Keputusan Tata Usaha Negara yang digugat; (e) gugatan diajukan sebelum waktunya atau telah lewat waktunya.

Dari ketentuan Pasal 62 tersebut sudah jelas rapat permusyawaratan berkaitan dengan penentuan apakah gugatan dapat diterima atau tidak. Sehubungan dengan Rapat Permusyawaratan yang merupakan prosedur dismissal ini dilakukan setelah gugatan melewati proses penelitian terhadap segi

8Yuslim, Op,.Cit,. hlm.111.

Bayu Septiawan: Penerapan Beban Pembuktian Oleh Hakim Dalam Penyelesaian Sengketa Di Pengadilan Tata Usaha Negara Bengkulu 
administratifnya, maka sebenarnya rapat permusyawaratan ini berkaitan erat dengan pemeriksaan administratif. Hasil penelitian secara admnistratif yang telah dibuatkan resume gugatanya dapat dijadikan bahan pertimbangan bagi Ketua Pengadilan dalam rapat permusyawaratan (Pasal 62). Dalam Rapat Permusyawaratan yang merupahkan bagian dari fungsi peradilan, Ketua Pengadilan memiliki kewenangan untuk memutuskan suatu penetapan yang dilengkapi dengan pertimbangan-pertimbangan bahwa gugatan yang diajukan dinyatakan tidak diterima atau berdasar yang menyangkut baik segi formil maupun materiil gugatan (Pasal 62 ayat 1).

Dalam angka II Surat Edaran Makamah Agung Nomor 2 Tahun 1991, disebutkan prosedur dismissal, sebagai berikut: ${ }^{9}$

1 a. Ketua Pengadilan berwenang memanggil dan mendengar keterangan para pihak sebelum menentukan Penetapan Dismissal apabila dipandang perlu.

b. Tenggang waktu yang ditentukan menurut Pasal 55 sejak tanggal diterimanya Keputusan Tata Usaha Negara oleh Penggugat, atau sejak diumumkannya keputusan tersebut, dengan ketentuan bahwa tenggang waktu itu ditunda (schors) selama proses peradilan masih berjalan menurut Pasal 62 jo. Pasal 63.

c. Dalam pada itu diminta agar ketua Pengadilan tidak terlalu mudah menggunakan Pasal 62 tersebut kecuali mengenai Pasal 62 ayat (1) butir a dan e.

1. Dilakukan oleh Ketua, dan Ketua dapat juga menunjuk seorang Hakim sebagai Raporteur (Raportir).

2. Penetapan Dismissal ditandatangani oleh Ketua dan Panitera Kepala/Wakil Panitera (Wakil Ketua dapat pula menanda tangani Penetapan Dismissal dalam hal Ketua berhalangan). Pemeriksaan Dismissal dilakukan secara singkat dalam rapat permusyaratan. Pemeriksaan gugatan perlawanan terhadap penetapan Dismissal juga dilakukan dengan acara singkat (Pasal 62 ayat 4).

3. Dalam hal adanya petitum gugatan yang nyata-nyata tidak dapat dikabulkan, maka dimungkinkan ditetapkan dismissal terhadap bagian petitum gugatan tersebut.

Ketentuan tentang perlawanan terhadap Ketetapan Dismissal juga berlaku dalam hal ini. Ketentuan yang terdapat dalam Surat Edaran Makamah Agung Nomor 2 Tahun 1991 tersebut, yang menyebutkan agar ketua pengadilan tidak terlalu mudah menggunakan wewenangnya, kecuali mengenai ketentuan Pasal 62 ayat (1) butir a dan e, yakni pokok gugatan tersebut nyata-nyata tidak termasuk dalam wewenang pengadilan (menyangkut kompentensi absolute atau relatif) dan gugatan diajukan sebelum waktunya (prematur) atau telah lewat waktunya.

Mengenai Putusan yang diambil oleh Ketua Pengadilan dalam rapat permusyawaratan (proses demisal) dibuat dalam bentuk (Pasal 62 ayat 1):10 (1) Suatu Penetapan oleh Ketua Pengadilan; (2) Dilengkapi dengan pertimbanganpertimbangan yang menjadi dasar putusan tersebut.

${ }^{9}$ Surat Edaran, Op.,Cit,. butir II

10W. Riawan Tjandra, Op.,Cit., hlm 93.

Bayu Septiawan: Penerapan Beban Pembuktian Oleh Hakim Dalam Penyelesaian Sengketa Di Pengadilan Tata Usaha Negara Bengkulu 
Dasar pertimbangan putusan pengadilan dalam rapat permusyawaratan untuk menyatakan gugatan tidak diterima atau tidak berdasar, dalam hal:11

a. Jika pokok gugatan nyata-nyata tidak termasuk dalam wewenang Pengadilan, maka gugatan dinyatakan tidak dapat diterima (Pasal 62 ayat 1 sub a). Pokok gugatan yang dimaksud adalah fakta yang dijadikan dasar gugatan yang kemudian atas dasar fakta tersebut. Penggugat mendalilkan adanya suatu hubungan hukum tertentu dan oleh karena itu mengajukan tuntutannya.

b. Jika syarat formil dalam Pasal 56 ayat (1) dan a dan b tidak dipenuhi oleh penggugat, maka gugatan dinyatakan tidak diterima dan jika syarat materiil dalam Pasal 56 ayat (1) sub c yang tidak terpenuhi, maka gugatan dinyatakan tidak berdasar (Pasal 62 ayat 1 sub b).

c. Jika gugatan tidak didasarkan pada alasan-alasan yang layak (Pasal 53 ayat 2), maka gugatan dinyatakan tidak berdasar (Pasal 62 ayat 1 sub b).

d. Jika apa yang dituntut sebenarnya sudah terpenuhi oleh Keputusan Tata Usaha Negara yang digugat, maka gugatan dinyatakan tidak diterima (Pasal 62 ayat 1 sub d).

e. Jika gugatan yang diajukan sebelum waktunya atau telah lewat waktunya, maka gugatan dinyatakan tidak dapat diterima Pasal 62 ayat 1 sub e).

2. Pemeriksaan di Persidangan.

Pemeriksaan dengan acara cepat dilakukan karena terdapat kepentingan Penggugat yang cukup mendesak yang dapat disimpulkan dari alasan-alasan permohonannya. Dalam penjelasan Pasal 98 Undang-Undang Peradilan Tata Usaha Negara dinyatakan bahwa bahwa kepentingan Penggugat cukup mendesak, apabila kepentigan itu menyangkut keputusan Tata Uasah Negara yang berisikan, misalnya perintah pembngkaran bangunan atau rumah yang ditempati Penggugat. Dalam hal ini yang dipercepat bukan hanya pemeriksaannya saja tetapi juga penjatuhan putusannya.

a. Pemeriksaan Persiapan (tertutup).

Pemeriksaan persiapan pada tahap ini sudah dipimpin oleh Hakim yang akan mengadili sengketa. Dengan kata lain, Ketua Pengadilan sudah menentapkan atau menujuk Hakim yang akan menagani sengketa tersebut. Pemeriksaan persiapan dalam proses pemeriksaan sengketa Tata Usaha Negara di Pengadilan, mewajibkan Hakim yang akan mengadili sengketa tersebut mengambil langkah-langkah aktif, seperti memberi nasehat kepada Penggugat untuk memperbaiki gugatannya. Pemeriksaan dapat dilakukan oleh hakim anggota yang ditunjuk oleh Ketua Majelis sesuai dengan kebijaksanaan yang ditetapkan oleh Ketua Majelis. ${ }^{12}$

Dalam Pasal 63 ayat (2) Undang-Undang Nomor 5 Tahun 1986 Jo. Undang-Undang Nomor 9 Tahun 2004 Jo. Undang-Undang Nomor 51 Tahun 2009 tentang Peradilan Tata Usaha Negara yang menyatakan bahwa, dalam pemeriksaan persiapan hakim;

${ }^{11}$ Ibid. hlm.94.

12 Surat Edaran, Op.,Cit,. butir III.

Bayu Septiawan: Penerapan Beban Pembuktian Oleh Hakim Dalam Penyelesaian Sengketa Di Pengadilan Tata Usaha Negara Bengkulu 
a. Wajib memberikan nasehat kepada penggugat untuk memperbaiki gugatan dan melengkapinya dengan data yang diperlukan dalam janga waktu tiga puluh hari. Memperbaiki gugatan misalnya Keputusan Tata Usaha Negara yang disengketakan bukan dibidang kepegawaian, tetapi Penggugat dalam gugatanya menuntut agar Tergugat melakukan rehabilitasi atas diri Penggugat yang bukan Pengawai Negeri Sipil. Melengkapi dengan data yang diperlukan, misalnya melengkapi gugatan dengan melampirkan Keputusan-keputusan Tata Usaha Negara yang disengketakan. Dalam Pasal 63 ayat (3) disebutkan bahwa apabila gugatan tersebut dalam jangka 30 hari penggugat tidak melakukan perbaikan terhadap gugatan atau Penggugat tidak hadir dalam pemeriksaan persiapan maka dalam hal keadaan yang demikian hakim dapat menyatakan putusan tidak dapat diterima.

b. Dapat meminta penjelasan kepada badan atau pejabat tata usaha negara.

Menurut Indroharto yang dimaksud dengan kalimat "yang bersangkutan" dalam perumusan Pasal 62 ayat (2) huruf adalah baik Tergugat maupun Badan atau jabatan Tata Usaha Negara dari instansi lain. ${ }^{13}$

Dalam surat edaran Makamah Agung diberikan petujuk lebih lanjut maksud dari Pasal 63 ayat (2) huruf b tersebut tidak terbatas hanya kepada Badan atau pejabat Tata Usaha Negara yang digugat saja, tetapi boleh juga terhadap siapa saja yang bersangkutan dengan data yang diperlukan untuk mematang perkara itu. ${ }^{14}$

Apa yang dimaksud dengan kata "penjelasan" dalam Pasal 63 ayat (2) huruf b, sama sekali tidak disebutkan dalam Undang-undang Nomor 5 Tahun 1986, tetapi yang jelas "penjelasan" yang dimaksud adalah penjelasan yang berkaitan dengan isi dan prosedur tentang dikeluarkannya Keputusan Tata Usaha Negara yang menimbulkan akibat sengketa Tata Usaha Negara tersebut. 15

Wewenang hakim untuk meminta penjelasan kepada badan atau pejabat Tata Usaha Negara tersebut menurut penjelasan Pasal 63 ayat (1) adalah untuk mengimbangi dan mengatasi kesulitan seserang sebagai Penggugat dalam mendapatkan informasi atau data yang diperlukan dari Badan atau pejabat Tata Usaha Negara mengingat Penggugat dan Badan atau pejabat Tata Usaha Negara kedudukannya tidak sama. ${ }^{16}$

Kewenagan hakim dalam pemeriksaan persiapan selain diatur dalam Pasal 63 Undang-Undang Peradilan Tata Usaha Negara, juga dijelaskan lagi dalam pelaksanaan pemeriksaan persiapan dalam Surat Edaran Makamah Agung Nomor 2 Tahun 1991 tentang petunjuk Pelaksanan Beberapa Ketentuan dalam UndangUndang Nomor 5 Tahun 1986. Bab III tentang pemeriksaan persiapan ${ }^{17}$ :

1. Tujuan pemeriksaan persiapan adalah untuk mematangkan perkara. Segala sesuatu yang akan dilakukan dari jalan pemeriksaan persiapan tersebut

13 Indroharto, Op,. Cit. hlm. 88.

14 Surat Edaran, Op., Cit,. butir III. 2 huruf c.

15 R. Wiyono,Buku Kedua, Op., Cit,.hlm 159

16 Ibid.

17 Surat Edaran, Op.,Cit,. butir III.

Bayu Septiawan: Penerapan Beban Pembuktian Oleh Hakim Dalam Penyelesaian Sengketa Di Pengadilan Tata Usaha Negara Bengkulu 
diserahkan kepada kearifan dan kebijaksanaan Ketua Majelis. Oleh karena itu dalam pemeriksaan persiapan memanggil Penggugat untuk menyempurnakan gugatannya dan/atau tergugat dimintai keterangan/penjelasan tentang keputusan yang digugat, tidak selalu harus didengar secara terpisah (Pasal 63 ayat $2 \mathrm{a}$ dan $\mathrm{b}$ ).

2. a) Pemeriksaan persiapan dilakukan di ruangan musyawarah dalam sidang tertutup untuk umum, tidak harus di ruangan sidang, bahkan dapat pula dilakukan di dalam kamar kerja Hakim tanpa memakai toga.

b) Pemeriksaan persiapan dapat pula dilakukan oleh Hakim Anggota yang ditunjuk oleh Ketua Majelis sesuai dengan Kebijaksanaan yang ditetapkan oleh Ketua Majelis.

c) Maksud Pasal 63 ayat (2) b tidak terbatas hanya kepada Badan/Pejabat Tata Usaha Negara, yang digugat, tetapi boleh juga terhadap siapa saja yang bersangkutan dengan datadata yang diperlukan untuk mematangkan perkara itu.

3. a) Dalam tahap pemeriksaan maupun selama pemeriksaan di muka persidangan yang terbuka untuk umum dapat dilakukan pemeriksaan setempat.

b) Dalam melakukan pemeriksaan setempat tidak perlu harus dilaksanakan oleh majelis lengkap, cukup oleh salah seorang Hakim Anggota yang khusus ditugaskan untuk melakukan pemeriksaan setempat Penugasan tersebut dituangkan dalam bentuk Penetapan.

c) Apabila dipandang perlu untuk menentukan dikabulkan atau tidaknya permohonan penundaan itu, oleh majelis yang bersangkutan dapat pula mengadakan pemeriksaan setempat.

4. Majelis Hakim yang menangani suatu perkara berwenang sepenuhnya untuk memberikan putusannya terhadap perkara tersebut, termasuk pemberian putusan menyatakan gugatan Penggugat tidak dapat diterima (niet onvankelijk verklaard) untuk seluruhnya atau sebagian gugatan, meskipun perkara itu telah lolos dari dismissal proses.

Sedangkan menurut Indroharto bahwa pemeriksaan persiapan itu dilakukan Hakim sebelum memeriksa pokok perkara dan dilakukan di muka sidang dimuka umum. Katakanlah dalam ruang kerja Hakim yang bersangkutan. Dalam priode pemeriksaan persiapan itu, dilakukan pengumpulan dokumendokumen atau informasi-informasi resmi yang diperlukan yang berkaitan dengan sengketa yang sedang diperiksa baik dari pihak Tergugat maupun Instansi-instansi lain. 18

Tujuan dari pemeriksaan persiapan ini adalah untuk dapat meletakan dalam peta baik mengenai obyek dan fakta-faktanya maupun mengenai problema hukum yang harus dijawab nantinya. Pengumpulan data-data tertulis terdiri

18 Indroharto, Op,.Cit. hlm. 89.

Bayu Septiawan: Penerapan Beban Pembuktian Oleh Hakim Dalam Penyelesaian Sengketa Di Pengadilan Tata Usaha Negara Bengkulu 
atas: $^{19}$ (a) Keterangan-keterangan resmi dari pihak pemerintah; (b) Keteranganketerangan resmi lainnya yang diperlukan yang mungkin juga didapat dari pihak ketiga; (c) pendapat dan dalil-dali dari para pihak sendiri.

Menurut Okta Orlando20, dalam proses pemeriksaan persiapan, kami selaku pihak Tergugat hanya menunggu apa yang dipinta dari pihak lawan. Berhubungan dengan obyek gugatan di Pengadilan Tata Usaha Negara itu berkaitan dengan Keputusan Tata Usaha Negara yang di keluarkan oleh Badan atau pejabat Tata Usaha Negara. Apabila hakim meminta penjelasan maka kami akan memberikannya, biasanya hakim memerintakan kepada pihak Tergugat untuk membuat kronologis dan dasar hukum, peraturan-peraturan yang menujang terbitnya obyek sengketa Keputusan Tata Usaha Negara yang digugat. Adapun isi kronologis tersebut terdapat hal-hal yang harus dijelaskan seperti: (1) Aturan dasar dikeluarkannya Keputusan Tata Usaha Negara; (2).Tentang mekanisme terbitnya Keputusan Tata Usaha Negara; (3) Menceritakan atau menggambarkan bahwa surat Keputusan Tata Usaha Negara tersebut sesuai dengan prosedur, subtansi dan kewenangan.

Menurut Suhendra dan Ari Prabowo,21 yang merupahkan Panitera PTUN Bengkulu yang memiliki tugas untuk membantu hakim dengan mengikuti dan mencatat jalanya persidang dipengadilan, Sebelum pemeriksaan pokok sengketa dimulai, hakim wajib mengadakan pemeriksaan persiapan untuk mengimbangi kedudukan penggugat yang berada dibawah kedudukan tergugat, maka majelis hakim memberi nasehat kepada Penggugat untuk memperbaiki gugatan yang kurang jelas dan meminta penjelasan kepada pejabat Tata Usaha Negara yang bersangkutan demi lengkapnya data yang diperlukan untuk gugatan tersebut agar kedudukan Pengugat dapat menjadi seimbang dengan Tergugat. Apakah selalu ada permintaan Penggugat meminta kepada Majelis hakim agar alat-alat bukti yang dimiliki oleh tergugat diberikan ? Menurut Fatma N.M Simbolon, ${ }^{22}$ selaku panitera PTUN Bengkulu, yang merupakan Ketua Panitera PTUN Bengkulu, mengenai alat bukti yang dimiliki oleh Tergugat itu diberikan dalam hal mengenai obyek sengketa keputusan Tata Usaha Negara yang digugat, maka Pengguat tidak memiliki obyek itu, maka Hakim memerintakan Tergugat dan meminta penjelasan alat bukti surat (pra bukti) yang berupa data, dokumen dan membuat kronologis terbitnya obyek sengketa Keputusan Tata Usaha Negara dan tahapan-tahapan prosedur dikeluarkannya keputusan tersebut. apabila Tergugat tidak mau memberikah semua informasi dan semua alat bukti kepada Majelis Hakim, apa konsekuensinya? mengenai konsekuensi sanksi dalam peraturan perundangundangan tidak mengatur hal tersebut, tapi apabila pejabat Tata Usaha Negara

${ }^{19}$ Ibid. hlm.90.

20 Wawancara dengan Okta Orlando dan Muhammad Arif, mewakili kuasa hukum kanwil BPN Provinsi Bengkulu, Tanggal 3 Juny 2017.

21 Wawancara dengan Suhendra dan Ari Prabowo, Panitera Pengadilan Tata Usaha Negara Bengkulu, di Bengkulu, 5 July 2017.

22 Wawancara dengan Fatma. N.M Simbolon, Ketua Panitera Pengadilan Tata Usaha Negara Bengkulu, di Bengkulu, 5 July 2017.

Bayu Septiawan: Penerapan Beban Pembuktian Oleh Hakim Dalam Penyelesaian Sengketa Di Pengadilan Tata Usaha Negara Bengkulu 
tidak memberikan kepada Majelis Hakim maka resiko ada pada pejabat Tata Usaha Negara sendiri. Namun hal tersebut berbeda menurut Erick. S. Sihombing, ${ }^{23}$ mengenai hal, apabila pejabat tersebut tidak memberikan informasi dan semua alat bukti kepada Majelis Hakim pada saat pemeriksaan persiapan maka Majelis Hakim bisa melakukan upaya paksa dan melakukan untuk meminta kepada atasan atau istansi lain yang berkaitan dengan surat keputusan tersebut.

Hakim Fajar Shiddiq Arfah24, mengatakan bahwa pada saat proses pemeriksaan persiapan, Hakim memberikan nasehat, memberikan petujuk untuk perbaikan gugatan yang kurang jelas, nasehat itu diberikan kepada Penggugat dalam pemeriksaan persiapan adalah menyakut gugatan yang belum sempurna atau kurang jelas bentuk formal gugatan, sebagaimana diatur dalam Pasal 56 Undang-Undang Nomor 5 tahun 1986. Namun menurut Andini25, nasehat yang diberikan hakim bukanlah nasehat yang bersifat memaksa sehingga apabila Penggugat tidak mendengarkan nasehat Hakim, maka hakim juga tidak dapat mengintervensi Penggugat.

Sementara itu hakim Sahibur Rasid 26 Nasehat mengatakan bahwa yang dapat diberikan dalam pemeriksaan persiapan adalah dalam hal bentuk formal gugatan yang belum jelas serta meminta data-data yang diperlukan untuk mendukung gugatan, tetapi nasehat yang diberikan oleh hakim kepada penggugat tidak sampai mengubah subyek dan obyek gugatan. sedangan kepada pihak tergugat diperintahkan untuk membuat kronologis terbitnya suatu keputusan tata usaha negara dan peraturan terkait yang menjadi dasar terbitnya suatu keputusan yang digugat tersebut. Hal tersebut sangatlah sesuai dengan asas keatifan hakim yang bertujuan untuk mengimbangi kedudukan para pihak yang tidak seimbang, Tergugat (Badan atau pejabat Tata Usaha Negara) sedangkan Penggugat (warga biasa).

b. Pemeriksaan di sidang terbuka untuk umum.

Pemeriksaan dengan acara biasa, mengikuti semua prosedur dan proses yang dimulai dengan pembacaan gugatan, penyampaian eksepsi atau jawaban, penyampaian replik, penyampaian duplik, telah selesai selanjutnya memasuki tahapan pembuktian baik berupa surat maupun keterangan saksi yang sangat menentukan putusan dalam proses peradilan. Pembuktian dalam hukum acara Peradilan Tata Usaha Negara diatur dalam Pasal 100 sampai dengan Pasal 107 Undang-Undang Peradilan Tata Usaha Negara.

Berbeda dengan ketentuan hukum acara perdata berdasarkan Pasal 1865 Kitab Undang-undang Hukum Perdata, yang menyatakan bahwa:" Barang siapa yang mendalilkan mempunyai suatu hak atau mengajukan suatu peristiwa untuk

23 Wawancara Hakim PTUN Bengkulu, Erick S. Sihombing, S.H. Di Pengadilan Tata Usaha Negara Bengkulu, Tanggal 19 Juny 2017.

24 Wawancara Hakim PTUN Bengkulu, Fajar Shiddiq Arfah, S.H. Di Pengadilan Tata Usaha Negara Bengkulu.Tanggal 19 Juny 2017.

25 Wawancara Hakim PTUN Bengkulu, Andini, S.H, Di Pengadilan

Tata Usaha Negara Bengkulu. tanggal 19 Juny 2017.

26 Wawancara Hakim PTUN Bengkulu, Sahibur Rasid, S.H. M, H, Di Pengadilan Tata Usaha Negara Bengkulu. Tanggal 19 Juny 2017.

Bayu Septiawan: Penerapan Beban Pembuktian Oleh Hakim Dalam Penyelesaian Sengketa Di Pengadilan Tata Usaha Negara Bengkulu 
menegaskan haknya atau untuk membantah adanya hak orang lain, haruslah membuktikan tentang adanya hak atau peristiwa tersebut". Berdasarkan Pasal 1865 Kitab Undang-undang Hukum Perdata, tentang beban pembuktian yang mendalilkan bahwa siapa yang menggugat, dialah yang membuktikan.

Ketentuan di atas tidak dianut dalam Pasal 107 Undang-Undang Nomor 5 Tahun 1986 tentang Peradilan Tata Usaha Negara yang diubah Undang-Undang Nomor 9 Tahun 2004 tentang Perubahan Undang-Undang Nomor 5 Tahun 1986 tentang Peradilan Tata Usaha Negara yang diubah Undang-Undang Nomor 51 Tahun 2009 tentang Perubahan Kedua Atas Undang-Undang Nomor 5 Tahun 1986 tentang Peradilan Tata Usaha Negara.

Menurut Syaiful Anuawar ${ }^{27}$ yang menjelaskan, Pada tahap pembuktian, para pihak diberikan kesempatan yang seluas-luasnya untuk mengajukan buktibukti untuk dapat mendukung dalil-dalil gugatan. Apakah pada saat persiapan pembuktian, adakah penetapan hakim untuk menentukan beban pembuktian, kepada siapa beban pembuktian diletakan, kapan pelaksanan penetapannya dilakukuan, apakah berjalan mengalir begitu saja? Karena dasar untuk mengajukan gugatan yang berkaitan dengan sengketa administrasi. siapa yang mendalilkan dialah yang harus dapat menyapaikan alat-alat bukti untuk menguatkan dalil-dalil gugatan. Karena menurut penglihatan keputusan tata usaha negara yang digugat tidak sah, bahwa adanya infosibel keputusan tata usaha negara yang dikeluarkan oleh pejabat tata usaha negara secara subtansi prosedur dan kewenagannya tidak sesuai dengan peraturan perundang-undangan, maka penggugat harus membuktikan hal tersebut.

Menurut Okta Orlando dan Muhammad Arif28, pada agenda memasuki tahap pembuktian, pembuktian itu pada dasarnya siapa yang dirugikan dialah yang membuktikan. Para pihak diberikan kesempatan yang sama dan seluasluasnya untuk mengajukan bukti-bukti yang mendukung dalil-dalil gugatannya atau sangkalan bukti lawan. Apakah pada saat persiapan pembuktian, adakah penetapan hakim untuk menentukan beban pembuktian, kepada siapa beban pembuktian diletakan, apakah berjalan mengalir begitu saja, bagaimana pelaksaannya? beban pembuktian itu adalah kewenagan hakim untuk menayakan kepada salah satu pihak, misalnya hakim meminta kepada Tergugat agar menjelaskan bukti surat tersebut, pada hal Tergugat tidak mendalilkan hal tersebut, maka Tergugat menjelaskannya, begitu juga sebaliknya kepada Penggugat. Pada pelaksanannya pembuktian yang dimulai dari pihak Penggugat untuk mengajukan bukti-bukti, karena Pengugat yang mendalilkan maka harus membuktian bukti tertulis setelah itu disangkalan atau bantahannya oleh pihak Tergugat. Pembuktian yang terlebih dahulu dari pihak Penggugat untuk mengajukan alat-alat bukti surat.

\section{Pertimbangan Hakim Dalam Menentukan Beban pembuktian Di Pengadilan Tata Usaha Negara Bengkulu}

Hakim sebelum menjatuhkan putusan terhadap perkara yang diperiksanya

27 Wawancara dengan Syaiful Anuawar, Kuasa hukum Penggugat, Kuasa hukum Penggugat, Tanggal 30 Juny 2017.

28 Wawancara dengan Okta Orlando, mewakili kuasa hukum kanwil BPN Provinsi Bengkulu, Tanggal 3 July 2017.

Bayu Septiawan: Penerapan Beban Pembuktian Oleh Hakim Dalam Penyelesaian Sengketa Di Pengadilan Tata Usaha Negara Bengkulu 
tentunya akan mempertimbangkan gugatan, yang terdiri dari tuntutan utama dan tuntutan tambahan. Tuntuntan utama yang menyatakan batal atau tidak sahnya suatu keputusan Tata Usaha Negara, sedangkan tuntutan tambahan yang menyatakan meminta ganti rugi dan rebilitasi (Pasal 53 ayat (1) Undang-Undang Peradilan Tata Usaha Negara). Dalam meneliti putusan Pengadilan Tata Usaha Negara Bengkulu yang dilakukan penulis dari Tahun 2015-2017, bahwa gugatan yang masuk berjumlah 37 (tiga puluh tujuh) sengketa Tata Usaha Negara, dari sekian jumlah sengketa tersebut, diklasifikasi lagi mengenai gugatan ditolak berjumlah 9 (sembilan) putusan, gugatan dikabulkan berjumlah 12 (dua belas) putusan, gugatan tidak diterima yang berjumlah 9 (sembilan) putusan, gugatan gugur 1 (satu) putusan, gugatan dicabut 2 (dua) putusan dan gugatan tidak diterima dalam proses demisal 2 (dua) putusan.

Dari semua putusan hakim yang berjumlah 30 (tiga puluh) putusan, dalam pertimbangan hukum, semuanya sama bahwa hakim tidak perna menjelaskan atau menentukan kepada siapa beban pembuktian itu diletakan. Bagaimana yang "tidak pernah" itu, maka dapat dilihat dalam Putusan Hakim, bagian pertimbangan hukum, yang menyebutkan:

Menimbang, bahwa setelah Majelis Hakim mempelajari Gugatan, Replik, Bukti Surat, dan Kesimpulan dari Penggugat dihubungkan dengan Jawaban, Duplik, Bukti Surat, dan Kesimpulan dari Tergugat, selanjutnya berdasarkan kewenangan Hakim Peradilan Tata Usaha Negara yang bersifat aktif (Dominus Litis) sebagaimana ketentuan Pasal 107 Undang-Undang Nomor 5 Tahun 1986 Tentang Peradilan Tata Usaha Negara, Majelis Hakim telah memeriksa seluruh alat bukti para pihak tersebut dan menemukan bukti-bukti yang memiliki relevansi dengan persengketaan a quo sehingga dapat dijadikan sebagai bahan pertimbangan dan berdasarkan bukti-bukti tersebut Majelis Hakim menemukan fakta- fakta hukum. ${ }^{29}$;

Menimbang, bahwa untuk mengutkan dalil-dalil gugatanya, Penggugat telah mengajukan bukti-bukti tertulis berupa fotokopi surat-surat bermeterai cukup yang di beri tanda P-. ; Menimbang bahwa Penggugat tidak mengajukan Saksi walapun telah diberikan kesempatan yang cukup.

Menimbang, bahwa untuk mengutkan dalil-dalil jawabannya, Tergugat telah mengajukan bukti-bukti tertulis berupa fotokopy surat-surat yang bermeterai cukup yang diberi tanda T-. ;

Menimbang bahwa Terggugat tidak mengajukan Saksi walapun telah diberikan kesempatan yang cukup. ${ }^{30}$

Menutut Indroharto Beban pembuktian adalah kewajiban yang dibebankan kepada suatu pihak untuk membuktikan suatu fakta dimuka Hakim yang sedang memeriksa perkara itu. ${ }^{31}$

Pasal 1865 Kitab Undang-Undang Hukum Perdata, tentang beban pembuktian, yang menyatakan bahwa:"Setiap orang yang mengaku mempunyai suatu hak, atau menunjukan suatu peristiwa untuk meneguhkan haknya itu atau

${ }^{29}$ Putusan No.02/G/2017/PTUN-BKL, diunduh Tanggal 29 Mei 2016, hlm 21 25.

30 Ibid. hlm. 31.

31 Indroharto, Loc, Cit.

Bayu Septiawan: Penerapan Beban Pembuktian Oleh Hakim Dalam Penyelesaian Sengketa Di Pengadilan Tata Usaha Negara Bengkulu 
untuk membantah suatu hak orang lain, wajib membuktikan adanya hak itu atau kejadian yang dikemukakan itu".

Dapat dikatakan bahwa Pasal 1865 Kitab Undang-Undang Hukum Perdata, bagian Buku Keempat, barang siapa yang menggugat, dialah yang membuktikan. Ketentuan diatas tidak dianut dalam Pasal 107 Undang-Undang Nomor 5 Tahun 1986 tentang Peradilan Tata Usaha Negara yang diubah Undang-Undang Nomor 9 Tahun 2004 tentang Perubahan Undang-Undang Nomor 5 Tahun 1986 tentang Peradilan Tata Usaha Negara yang diubah Undang-Undang Nomor 51 Tahun 2009 tentang Perubahan Kedua Atas Undang-Undang Nomor 5 Tahun 1986 tentang Peradilan Tata Usaha Negara., yang menyatakan bahwa : Hakim menentukan apa yang harus dibuktikan, beban pembuktian berserta penilaian pembuktian, dan untuk sahnya pembuktian perlu sekurang-kurangnya dua alat bukti berdasarkan keyakinan hakim.

Dalam pasal tersebut, hakim diberikan kebebasan untuk menentukan apa yang harus dibuktikan, beban pembuktian dan penilaian pembuktian. Selanjutnya dalam Pasal 80 juga menjelaskan bahwa beban pembuktian tidak hanya datang dari pihak yang bersengketa. Artinya Hakim dalam memeriksa, memutus dan menyelesaikan sengketa Tata Usaha Negara, Hakim mempunyai kebebasan atau dapat menentukan sendiri siapa yang harus dibebani pembuktian. Dipertegas lagi dengan Penjelasan Pasal 107 menyatakan bahwa pasal ini mengatur ketentuan dalam rangka usaha menemukan kebenaran materiil. Berbeda dengan sistem hukum pembuktian dalam Hukum Acara Perdata, maka dengan memperhatikan segala sesuatu yang terjadi dalam pemeriksaan, tanpa tergantung pada fakta dan hal yang diajukan oleh para pihak, Hakim Peradilan Tata Usaha Negara dapat menentukan sendiri: (a) apa yang harus dibuktikan; (b) siapa yang harus dibebani pembuktian, hal apa yang harus dibuktikan oleh pihak yang berperkara dan hal apa saja yang harus dibuktikan oleh Hakim sendiri; (c) alat bukti mana saja yang diutamakan untuk dipergunakan dalam pembuktian; (d) kekuatan pembuktian yang telah diajukan

Untuk mengetahui tentang pertimbangan hakim dalam menentukan beban pembuktian Dalam hal ini penulis melakukan wawancara dengan beberapa Hakim. Adapun hasil wawancara penulis dengan beberapa Hakim sebagai berikut: Hakim Fajar Shiddiq Arfah ${ }^{32}$, menjelaskan, pelaksanan pembuktian yang dimulai dari alat bukti surat, dan keterangan saksi, pada dasarnya diberikan seluas-luasnya dan sebesar-besarnya kepada masing-masing pihak yang bersengketa untuk membuktikan alat bukti yang diajukan dalam persidangan, apabila bukti surat tersebut kurang relavan maka hakim meminta lagi bukti surat tersebut, yang berkaitan dengan obyek sengekta Tata Usaha Negara atas terbitnya suatu Keputusan Tata Usaha Negara yang digugat.

Berdasarkan pendapat tersebut dapat disimpulkan bahwa pertimbangan hakim memberikan seluas-luasnya kepada masing-masing pihak. kata seluas-

32 Wawancara dengan Hakim PTUN Bengkulu, Fajar Shiddiq Arfah, S.H. Di PTUN Bengkulu, Tanggal 05 July 2017.

Bayu Septiawan: Penerapan Beban Pembuktian Oleh Hakim Dalam Penyelesaian Sengketa Di Pengadilan Tata Usaha Negara Bengkulu 
luasnya itu tidak dapat dikatakan itu beban pembuktian, tetapi kata seluasluasnya merupakan salah satu asas peradilan dalam hukum acara yaitu Asas Audi Et Alteram Partem, merupakan implementasi dari asas persamaan, dimana hakim tidak boleh membeda-bedakan antara Penggugat dan Tergugat dan Hakim harus bersifat adil terhadap kedua belah pihak.

Asas Audi Et Alteram Partem adalah asas yang mewajibkan hakim untuk mendengar kedua belah pihak secara bersama-sama. Hakim tidak boleh hanya mendengar keterangan satu pihak saja, tapi harus juga mendengar dan memberi kesempatan kepada pihak lainnya untuk mengemukakan pendapat atau keterangannya ${ }^{33}$. Demikian pula dalam hal kesempatan memberikan alat-alat buktinya dan menyampaikan kesimpulannya, termasuk dalam pengertian mendengar tersebut ${ }^{34}$.

Hakim Sahibur Rasid, dan Ulia Alba ${ }^{35}$, menjelaskan, mulainya masuk berkas perkara sampai ke agenda pembuktian hakim sudah mengetahui apa yang harus dibuktikan, pada saat pemeriksaan persiapan telah meminta kepada kedua belah pihak untuk membawa alat bukti tersebut yang akan diajukan pada saat agenda pembuktian. Pada saat memasuki ageda pembuktian para pihak diberikan seluas luasnya untuk mengajukan alat bukti, maka Majelis akan melihat, apa yang harus dibuktikan, apabila bukti itu kurang relavan maka Majelis Hakim dapat meminta alat bukti surat tersebut yang berkaitan dengan obyek sengketa Tata Usaha Negara bisa kepada Pengugat maupun Tergugat. Apabila bukti itu tidak dapat dibuktikan, maka disitulah penilaian hakim mengenai alat bukti tersebut. Berdasarkan hasil wawancara dengan Hakim Sahibur Rasid, Riki Yudiandi, Andini dan Erick. S. Sihombing36, menjelaskan Apabila bukti itu satu-satunya bukti kunci harus dihadirkan dan diperlihatkan, kalau memang pihak ini upamanya Penggugat atau Terggugat berusaha saling menutup nutupi atau tidak kreatif, maka majelis bisa melakukan pemeriksaan setempat, tapi sebenarnya dari bukti-bukti yang diajukan oleh para pihak yang bersengketa dinilai sudah cukup dan itu hanya untuk memperkuat lagi dan menambah keyakinan hakim, bahwa hal ini harus dibuktikan untuk memperkuat bukti-bukti yang ada dan untuk penambah saja maka hakim tidak memaksa lagi karena prakteknya seperti itu. Masalahnya yang diajukan para pihak, Hakim sudah menemukan bukti-bukti tersebut, untuk menambah keyakinan hakim.

Menurut Indroharto luas pembuktian, artinya mula-mula hakim menentukan fakta-fakta apa yang relavan bagi putusan ahkir nanti. Sesudah itu hakim meneliti menurut keyakinannya fakta-fakta mana yang dianggap cukup

33 Marbun, Peradilan Administrasi Dan Upaya Administratif Di Indonesia, UII Pres, Jogjakarta, 2003, hlm. 160.

34 Ibid.

35 Wawancara dengan Hakim PTUN Bengkulu, Sahibur Rasid, S.H. M, H, dan Ulia Alba, S.H. M, H. Di PTUN Bengkulu, Tanggal 19 Juny 2017.

36 Wawancara Hakim PTUN Bengkulu, Sahibur Rasid, Riki Yudiandi, S.H. M.H, Andini, S.H. dan Erick. S. Sihombing, S.H. Di PTUN Bengkulu, Tanggal 19 Juni 2017.

Bayu Septiawan: Penerapan Beban Pembuktian Oleh Hakim Dalam Penyelesaian Sengketa Di Pengadilan Tata Usaha Negara Bengkulu 
pasti. Kemudian ia melihat fakta-fakta mana saja lagi yang yang masi perlu dibuktikan. Ini semua dimaksud dengan luas pembuktian. ${ }^{37}$

\section{PENUTUP}

\section{Simpulan}

Penerapan beban pembuktian di Pengadilan Tata Usaha Negara Bengkulu, dari Tahun 2015-2017 yang berjumlah 30 (tiga puluh) berkas perkara di Pengadilan Tata Usaha Negara Bengkulu, Hakim tidak pernah menentukan beban pembuktian, sementara dalam Pasal 107 Undang-Undang tentang Peradilan Tata Usaha Negara adalah dasar sistem pembuktian di peradilan Tata Usaha Negara, yang mana Hakim menentukan beban pembuktian kepada salah satu pihak baik Penggugat maupun Tergugat. Melainkan kepada kedua-duanya, bahkan mewajibkan kepada Penggugat untuk membuktikan terlebih dahulu alat bukti yang diajukan di persidangan seperti lazimnya dalam sistem peradilan hukum acara perdata yang diatur dalam Pasal 1865 Kitab Undang-Undang Hukum Acara Perdata. Sementara itu dalam berkas putusan tidak ditemukan pertimbangan hakim mengenai beban pembuktian kepada salah satu pihak baik Penggugat maupun Tergugat. Dengan demikian dapat dikatakan bahwa bahwa Hakim tidak pernah menentukan beban pembuktian.

\section{Saran}

Fungsi Pengadilan Tata Usaha Negara, memberi perlindungan hukum bagi masyarakat yang dirugikan atas dikeluarkannya Keputusan Tata Usaha Negara oleh pejabat Tata Usaha Negara kepada orang atau badan hukum perdata, adanya ketidakseimbangan kedudukan antara Tergugat dengan Penggugat. Maka seharusnya Hakim Pengadilan Tata Usaha Negara Bengkulu melaksanakan Pasal 107 terkususnya mengenai beban pembuktian dan menentukan kepada salah satu pihak Tergugat maupun Penggugat untuk membuktikan. Bahkan Hakim dapat membebankan kepada Tergugat dalam kasus-kasus tertentu untuk membuktikan bahwa dalam mengeluarkan Keputusan Tata Usaha Negara atau tidak mengeluarkan Keputusan Tata Usaha Negara atau melakukan tindakan atau tidak melakukan tindakan.

\section{DAFTAR PUSTAKA}

Abdullah, H. Rozali, 2013,Hukum Acara Peradilan Tata Usaha Negara. PT. Raja Grafindo Persada,Jakarta.

Anuawar, Syaiful (Kuasa hukum Penggugat), 2017, Hasil Wawancara, Bengkulu, Tanggal 30 Juni.

Arfah, Fajar Shiddiq, S.H. (Hakim PTUN Bengkulu),2017, Hasil Wawancara, Bengkulu Tanggal 05 July.

Bambang, Waluyo, 1996. Sistem Pembuktian Dalam Peradilan Indonesia, Sinar Grafika, Jakarta.

37 Indroharto, Op., Cit, hlm. 190.

Bayu Septiawan: Penerapan Beban Pembuktian Oleh Hakim Dalam Penyelesaian Sengketa Di Pengadilan Tata Usaha Negara Bengkulu 
Hadjon, Philipus M., 1993, (et al), Pengatar Hukum Administrasi Indonesia (Introduction To Indonesian Administrarive Law), Penerbit Gadjah Mada University Press, Yogyakarta.

Indroharto, 1999, Usaha Memahami Undang-Undang Tentang Peradilan Tata Usaha Negara Buku II Beracara Di Pengadilan Tata Usaha Negara, Pustaka Sinar Harapan, Edisi Revisi, Jakarta.

Kansil, C.S.T., 1991, Hukum Acara Peradilan Tata Usaha Negara, Cetakan Kedua, Penerbit PT. Pradnya Paramita.

2003, Hukum Acara Peradilan Tata Usaha Negara, Cetakan Keempat, Penerbit PT. Pradnya Paramita.

Khairo, Fatria, 2016, Hukum AcaraPeradilan Tata Usaha Negara, Penerbit Cintya press-Jakarta.

Kitab Undang-Undang Hukum Perdata, Penerbit Pustaka Mahardika.

Marbun, 2003, Peradilan Administrasi Dan Upaya Administratif Di Indonesia, UII Pres, Jogjakarta.

Mawardi, Irvan, 2016,Paradigma Baru PTUN, Respon Peradilan Administrasi Terhadap Demokratisasi, Penerbit Thafa Media,Yogyakarta.

Orlando, Okta (Kuasa Hukum Tergugat, kanwil BPN Provinsi Bengkulu), 2017, Hasil wawancara, Bengkulu, Tanggal 3 Juli.

Pedoman Teknis Administrasi dan Teknis Peradilan Tata Usaha Negara, 2008, Buku II, Edisi 2007, Makamah Agung.

Prodjohamidjojo, Martiman, 1997, Hukum Pembuktian Dalam Sengketa Tata Usaha Negara Uu No. 5 Tahun 1986, Ln No 77, Pt Pradnya Paramita, Jakarta.

Rasid, Sahibur, S.H. M, H,.(Hakim PTUN Bengkulu), 2017, Hasil Wawancara, Bengkulu, Tanggal 19 Juni.

Setiadi, Wicipto, 1995. Hukum Acara Pengadilan Tata Usaha Negara Suatu Perbandingan, Rajagrafindo Persada, Jakarta.

Simbolon, Fatma. N.M (Panitera Pengadilan Tata Usaha Negara Bengkulu), 2017, Hasil Wawancara, Bengkulu, tanggal, 5 July.

Suhendra dan Ari Prabowo (Panitera Pengadilan Tata Usaha Negara Bengkulu), 2017, Hasil wawancara, Bengkulu, tanggal 5 July 2017.

Supandi,2011, Hukum Peradilan Tata Usaha Negara (Kepatuhan Hukum Pejabat Dalam Menaati Putusan Pengadilan Tata Usaha Negara), Pustaka Bangsa Press, Medan.

.., 2016, Kapita Selekta Hukum Tata Usaha Negara, Penerbit P.T. Alumni, Bandung.

Suratman dan Philips Dillah, 2012, Metode Penelitian Hukum, Penerbit Alfabeta Bandung.

Surat Edaran Mahkamah Agung Nomor. 2 Tahun 1991 tentang petunjuk Pelaksanan Beberapa Ketentuan dalam Undang-Undang Nomor 5 Tahun 1986 diatur mengenai Penelitian Administrasi.

Tjandra, W. Riawan, 2011, Teori Dan Praktek Peradilan Tata Usaha Negara, Edisi Revisi, Cahaya Atma Pustaka, Yogyakarta.

Undang-Undang Dasar Republik Indonesia Tahun 1945

Undang-Undang Nomor 5 Tahun 198 6tentang Peradilan Tata Usaha Negara.

Bayu Septiawan: Penerapan Beban Pembuktian Oleh Hakim Dalam Penyelesaian Sengketa Di Pengadilan Tata Usaha Negara Bengkulu 
Undang-Undang Nomor 9 Tahun 2004 tentang Perubahan Atas Undang-undang Nomor 5 tahun 1986 Tentang Peradilan Tata Usaha Negara.

Undang-Undang Nomor 51 Tahun 2009 tentang Perubahan Kedua Atas UndangUndang Nomor 5 Tahun 1986 tentang Peradilan Tata Usaha Negara.

Undang-Undang Nomor 30 Tahun 2014 tentang Administrasi Pemerintah.

Wiyono, R., 2009, Hukum Acara Peradilan Tata Usaha Negara, Penerbit Sinar Grafika, Edisi Kedua, Jakarta.

2013,Hukum AcaraPeradilan Tata Usaha Negara, Penerbit Sinar Grafika, Edisi Ketiga, Jakarta.

Yanto, Nur., 2015, Hukum Acara Peradilan Tata Usaha Negara, (Suatu Teori Dan Prakteknya di Pengadilan Tata Usaha Negara Indonesia,) Penerbit Mitra Wacana Media.

Yudiandi, Riki, S.H. M.H, dan Erick. S. Sihombing, S.H. (Hakim PTUN Bengkulu), 2017, Hasil Wawancara, Bengkulu, Tanggal 19 Juni.

Yuslim, 2015, Hukum AcaraPeradilan Tata Usaha Negara, Cetakan Pertama, Sinar Grafika, Jakarta.

Bayu Septiawan: Penerapan Beban Pembuktian Oleh Hakim Dalam Penyelesaian Sengketa Di Pengadilan Tata Usaha Negara Bengkulu 